\title{
Aceh Women in Mass Media (Analysis Of Norman Critical Facts Fairclough On Violence News In Merdeka.Com Site)
}

\author{
Fitri Meliya Sari \\ \{fitri.meliyasari@serambimekkah.ac.id\}
}

Islamic Broadcast Communication, Serambi Mekkah University, Batoh, Banda Aceh, Aceh, Indonesia

\begin{abstract}
This research was a study conducted on news text published in Merdeka.com. Focusing on the news of violence experienced by women in Aceh. This study aimed to describe the way Merdeka.com discoursing Acehnese women who subjected to violence, as well as uncover the ideology held by Merdeka.com as anational media that wasn't related to regional regulations in Aceh. Analysis was done by Critical paradigm and Critical Discourse Analysis (CDA) model of Norman Fairclough. Cultural Radical Feminism and Muted Group Theory were used to explain the muting process over Acehnese women in news on common violence which couldn't be regarded as ordinary violence. This study showed that there wasn't any policy decisiveness in Merdeka.com which influenced by patriarchal ideology and Islamic law regulations through a men's way of thinking and acting in the news writing on women who subjected to violence. Although there were defenses from the National Commission for Women, the patriarchal concept was still more prominent which is similarly carried by the local media in Aceh. Finally, this study is expected to be a reference for Merdeka.com in writing news about women to be more impartial and gender conscious. As well as the Aceh government can implement the Islamic law which does not discriminate the women.
\end{abstract}

Keywords: News, Violence, Women, Muted Group, Islamic Sharia.

\section{Introduction}

Cases of violence are very widespread and things have been going on for a long time throughout the world. As published in Tempo.co, Komnas Perempuan data in 2014 showed that the number of violence against women was 293,220 cases. This number increased compared to 279,688 cases in 2013. Violence against women has also occurred in Aceh long ago even today. Whereas currently Aceh has implemented a regional regulation called the Islamic Shari'a Qanun. The reporting of violence against women in Aceh is widely considered due to the existence of Islamic Sharia. So many media blame the existence of Islamic Sharia. Throughout February 2012, Sharia News Watch monitored news about Islamic Shari'a on 18 print and online media in Aceh and nationally. The monitored print media are Serambi Indonesia, Harian Aceh, Aceh People, Metro Aceh, Prohaba, Tabloid Modus, Waspada, Analisa, Kompas, Republika, Media Indonesia, The Jakarta Post and Koran Tempo. 
Meanwhile,online media are acehkita.com, acehcorner.com, atjehpost.com, the globe journal.com, and thejakartaglobe.com. During February, there were 70 news related to Islamic law adorning the face of the media. News related to the arrest of citizens who allegedly violated the Shari'a became the most issue produced by the media. From the results of monitoring carried out by Aji Banda Aceh, it can be seen that the news related to the enforcement of Islamic law which is published in the media is far from what is expected. One function of the media as a means of social control in the implementation of Islamic law can be said to be weak. The media in the news of the new Shari'a are capable of providing information only and cannot yet become a means of social control, even though the media is the holder of the mandate of the fourth pillar of democracy.

The Islamic Sharia Qanun does not only regulate women but all Acehnese people. Too much reporting about Aceh and all its cases makes people often have negative thoughts about Aceh. News of gender bias is also rampant. Whereas in the journalistic code of ethics there is no article that corners one party. Where news must be balanced. Media coverage has a huge impact on society. Looking at the background, the problem can be formulated:

1. How is Merdeka.com reporting sexual violence against Acehnese women?

2. How is Merdeka.com's ideology in reporting sexual violence against Acehnese women?

\section{Literature Riview}

\subsection{Muted Group Theory}

The Muted Group Theory is based on the work of anthropologist Shirley Ardener [1], who argues that the status of society overlaps in which women and men are in a patriarchal system and capitalist society. And the perspective of women is limited by horse goggles and their voices are not articulated publicly. Deadly is different from silence, lethal success when subordinate groups (women) stop to find and develop communication styles to express themselves. This theory comes from Edward Sapir (1884-1939) and Benjamin Lee Whorf (1897-1941) with the mother tongue hypothesis having an important impact on how one perceives the world. This then gives rise to two distinct lines: (a) the deterministic view states that the structure of certain languages (for example, grammar and semantics) determines the speakers of the way the language sees the world / reality; and (b) on the contrary, relativistic views do not think language to determine our perceptions, but to influence us towards certain views of reality. In the mass media, women are highlighted as being weak and naturally experiencing violence, especially if there are certain regulations that are violated or not fully carried out as stated. The existing Islamic Shari'a is designed to regulate the Muslim community of Aceh to act in accordance with the rules of the Islamic religion. But there are only people who violate these rules. When the rule is violated especially in cases of violence, the media will load it in neutral language. In reality, neutrality remains gender-conscious so there is a silencing of women.

\subsection{Radical Feminist}

In this study using radical cultural feminist theory, where this feminist movement is against things that smell at the existing ism. Cases of violence that have certain politics against women can also be seen, such as the amount of violence that occurs because of the assumption that women are weak and men are in power. In the news media the same thing happened. News about women is a very interesting topic especially if it shows the weaknesses. In the loading of news sometimes many use the patriarchal side in the use of language, such as the 
use of the word "beautiful widow" or other. And things like this are strongly opposed by cultural radical feminist experts because of the empowerment of women in reporting so that news is interesting. Women as objects of reporting.

\subsection{Violence in women}

The term violence is used to describe behavior, both open and closed, attacking, defending, accompanied by the use of force against others. According to [2], quoting Pascal Lardellier, violence is a principle of action that bases itself on the power to force other parties without approval. In [3] explains violence according to Galtung is a condition that will occur if humans are influenced by such a way that actual physical and mental realization is under its potential realization. According to Windhu, Luhulima and Fry in [3]violence has several dimensions, including: (1) forms of violence (physical, psychological, sexual, financial, spiritual, and functional); (2) the effects of violence (negative or positive); (3) violence participants (subject and object); (4) violent motives; and (5) sources of violence (structural or personal). In this study the violence discussed was all violence against women in the mass media especially at Merdeka.com. Women are made objects of reporting and packaged as attractive as possible so that the news can be sold. News about women in Aceh is also very interesting news, especially if it relates to violations that are intentionally or unintentionally committed. Want that news about violations of Islamic Sharia and rape experienced by Acehnese women.

\subsection{Qanun Syariat Islam di Aceh}

Islamic Shari'a in Indonesia has a different understanding in each region. And this term is very political. The word "Shari'a" is a term contested by various parties who have a particular interest. Sharia-based regional regulations in Aceh are implemented because this region has special autonomy and distinguishes Aceh from other regions. And the background of this regulation is due to the long-standing conflict between GAM and the central government. Shari'a regional regulations are a solution to reduce existing conflicts. the implementation and implementation of Islamic law is a continuation of the status of Aceh's special autonomy as stipulated in Law No. 18 of 2001.

\subsection{Gender ideology as the dominant ideology}

The anthropologist, Alice Schlgel, uses the term gender meaning which has a meaning similar to gender ideology. We can mean gender ideology as the dominant ideology as part of the dialectical process between systems that are in society with one another. This means that an ideology referred to as a part of a dominant tool or mechanism can be included in all aspects of society. This view assumes that in fact there is rarely a rule that is purely a joint consensus. In this case the media plays an important role in directing and controlling the form of debate or discourse that arises. The media can convey certain interests, either opposition or acceptance of regulations such as Islamic Shari'a in the community and the world.

\subsection{Media Policy}

Policy is a series of concepts and principles that are outlines and plans in the implementation of a job / leadership and how to act [4]. According to Ealau and Pewitt, the policy is an applicable regulation, characterized by consistent and repetitive behavior from those who make or implement the policy. In daily mass communication, people use the media. The media is a place to transmit messages from the sender to the recipient that can stimulate one's thoughts, feelings, interests and attention. News loading is selected first in the editor. The news that is loaded must be interesting and sensational news. Violence reporting will usually 
be more interesting if the victim or perpetrator is a woman, especially if the case occurs in a remote area or is unique. Usually the area is unique and women will be the object of the news.

\section{Research Methodology}

This study uses a qualitative approach with a critical paradigm in the form of critical discourse analysis. Qualitative methods aim to explain phenomena in depth through deep data collection (Rachmat Kriyantono, 2009: 56). Operationally, this study seeks to describe the process of Critical Discourse Analysis regarding the text / language of reporting cases of violence against Acehnese women in the mass media, especially in the online media "Merdeka.com". This research was conducted in the online daily Merdeka.com. Merdeka.com was chosen as the object of the study because researchers had conducted pre-research on several existing online news sites and showed that from January 2013 to December 2014 more were published on the Merdeka.com website. There are even some media such as Yahoo.com and some other online media that also participated in launching news about Aceh from Merdeka.com. And also the researchers want to see how the mass media outside Aceh report about events that occurred in Aceh, especially news about Acehnese women.

The research subject is the subject intended by the researcher to be researched, it can be in the form of people or whatever is the source of research. The subject of this research was news of violence against Acehnese women from January 2013 to December 2014 on the online site Merdeka.com, the managing editor or journalist who wrote the topic, and also the news reader who commented on the news site about violence against Acehnese women in Merdeka.com.

The main data used in [5] Critical Discourse Analysis is from the text in the form of framing analysis from news about Acehnese women at Merdeka.com. From discourse practice in the form of interviews with editors or journalists of Merdeka.com. And socio-cultural practices from the ideology or regulations of the Aceh region. Secondary data is a support in the form of writing or drawing. This data is a literature about the study of Critical Discourse Analysis associated with mass communication, whose data is obtained from books, research journals, articles, and the internet.

Data collection techniques used in this study are: Microlevel analysis, analyzing the text carefully and focus in order to obtain data that can describe text representation. The text in this study was obtained directly from the framing analysis of news of violence against women in Aceh which was published on the online site Merdeka.com. The framing analysis used is a model from Robert N. Entman. In Entman's conception, framing basically refers to the provision of definitions, explanations, evaluations, and recommendations in a discourse to emphasize a certain frame of mind towards the discourse events [6].

Discourse Practice or Mesolevel Analysis, focused on two aspects, namely text production and text consumption. And the primary data from the discourse practice in the production process was obtained from the interview of the managing editor or Merdeka.com journalist, while the consumption was obtained from the news readers' comments on violence against Acehnese women posted on the Merdeka.com online site. Sociocultural Practice or Macrolevel Analysis focuses on the phenomenon in which the text is created. The sociocultural practice primary data in this study is not directly related to the production of text, but determines how the text is produced and understood, namely the conditions of Aceh that are implemented by the Qanun of Islamic Law in Aceh and the media ideology. 


\subsection{Results and Discussion of Research}

Violence against women is increasingly rampant. Women experience violence both physically and psychologically, not only that, even in local regulations women are always marginalized. Women are more silent. Even when experiencing sexual violence women will usually become the object of discussion and bear the shame of that. Women as victims of violence do not always get legal protection in accordance with what the perpetrators do to them as victims. The punishment received by the perpetrator is sometimes lighter than the suffering experienced by the victim.

In this study, researchers wanted to see about all kinds of violence experienced by Aceh women published by Merdeka.com as one of the national online media. In local Acehnese media women are not given room to speak out. Local media contains more about local regulations that should be carried out correctly. Women are not given a place to voice themselves. In contrast to national media which is more common. Not bound by certain regional regulations and also an understanding of women's rights more broadly. So that women should be able to voice themselves more loudly towards what is experienced.

Where national media should have more value conventions than local Acehnese media. National media should be able to support women to be able to voice their voices because in Aceh they are held back by regional regulations that are widely supported by the media. And the national media should be able to see in terms of reporting that is different from that published in the local media.

But in the news in the national media women also experienced the same thing. Media crews are usually more likely to use controversial news to attract readers. Women as objects of violence will be able to attract public attention. What is very unfortunate is that when women become victims of violence, they are not defended instead they tend to be targeted to attract community interest. The framing of the news raised is the side of the suffering experienced by the victim. Not the defense side so that victims can be protected. In reporting the patriarchal side sometimes it is very strong. Text shows the language used does not help victims of violence in fighting for their rights. Media that should be a balanced means of delivering news often also blame victims. The perpetrators also have more room to express their opinions. Media that has an important role in conveying information can influence the mindset of the community.

\begin{tabular}{|c|c|c|c|c|c|}
\hline $\begin{array}{c}\text { Framing } \\
\text { Entman }\end{array}$ & News I & News II & News III & News IV & News $V$ \\
\hline $\begin{array}{l}\text { Defined } \\
\text { problems }\end{array}$ & $\begin{array}{l}\text { Recognition of } \\
\text { women who } \\
\text { experience } \\
\text { sexual violence } \\
\text { by mass media } \\
\text { (P1, K1 and K2; } \\
\text { P6, K1). }\end{array}$ & $\begin{array}{l}\text { Men who } \\
\text { commit acts } \\
\text { of sexual } \\
\text { violence are } \\
\text { given more } \\
\text { room to } \\
\text { move, while } \\
\text { women are } \\
\text { either } \\
\text { silenced by } \\
\text { the state } \\
\text { apparatus or } \\
\text { the mass } \\
\text { media (P1, } \\
\text { K1, K2 and } \\
\text { K3). }\end{array}$ & $\begin{array}{l}\text { The mass } \\
\text { media gives a } \\
\text { picture that } \\
\text { men have the } \\
\text { power to do } \\
\text { violence } \\
\text { against } \\
\text { women, } \\
\text { especially in } \\
\text { families (P1, } \\
\text { K1 and K2; } \\
\text { and } \mathrm{P} 2, \mathrm{~K} 1) \text {. }\end{array}$ & $\begin{array}{l}\text { The media } \\
\text { shows the } \\
\text { superiority of } \\
\text { men towards } \\
\text { women who } \\
\text { are considered } \\
\text { patients } \\
\text { because they } \\
\text { need help (P1, } \\
\text { K1, K2; P2, } \\
\mathrm{K} 1, \mathrm{~K} 2 ; \mathrm{P} 7, \\
\mathrm{~K} 1, \mathrm{~K} 2 ; \text { and } \\
\mathrm{P} 8, \mathrm{~K} 1, \mathrm{~K} 2) \text {. }\end{array}$ & $\begin{array}{l}\text { The media } \\
\text { illustrates that } \\
\text { men can } \\
\text { commit all } \\
\text { forms of } \\
\text { crime, } \\
\text { whether rape } \\
\text { or theft (P1, } \\
\mathrm{K} 1 \text {; } \mathrm{P} 2, \mathrm{~K} 1 \text {, } \\
\mathrm{K} 2, \mathrm{~K} 3 ; \mathrm{P} 3 \text {, } \\
\mathrm{K} 1 ; \text { and } \mathrm{P} 6 \text {, } \\
\mathrm{K} 1, \mathrm{~K} 2) \text {. }\end{array}$ \\
\hline $\begin{array}{l}\text { Diagnose } \\
\text { causes }\end{array}$ & $\begin{array}{l}\text { Women are } \\
\text { considered }\end{array}$ & $\begin{array}{l}\text { Men who } \\
\text { commit rape }\end{array}$ & $\begin{array}{l}\text { The } \\
\text { perpetrator can }\end{array}$ & $\begin{array}{l}\text { The } \\
\text { perpetrators }\end{array}$ & $\begin{array}{l}\text { Perpetrators } \\
\text { can commit }\end{array}$ \\
\hline
\end{tabular}




\begin{tabular}{|c|c|c|c|c|c|}
\hline $\begin{array}{l}\text { Framing } \\
\text { Entman }\end{array}$ & News I & News II & News III & News IV & News $V$ \\
\hline & $\begin{array}{l}\text { perpetrators even } \\
\text { though there is } \\
\text { no clear } \\
\text { evidence and } \\
\text { experience } \\
\text { sexual violence } \\
\text { in the form of } \\
\text { rape }(\mathrm{P} 1, \mathrm{~K} 1 \text { and } \\
\mathrm{K} 2 \text {; } \mathrm{P} 3, \mathrm{~K} 1) \text {. }\end{array}$ & $\begin{array}{l}\text { are given } \\
\text { more space } \\
\text { to act in self- } \\
\text { defense (P1, } \\
\mathrm{K} 1 \text { and } \mathrm{K} 2 \text {; } \\
\mathrm{P} 2, \mathrm{~K} 2) \text {. }\end{array}$ & $\begin{array}{l}\text { silence his } \\
\text { family by } \\
\text { threatening } \\
\text { because he } \\
\text { feels that he is } \\
\text { a family leader } \\
\text { and superior } \\
\text { (P4, K1, K2 } \\
\text { and P5, K1). }\end{array}$ & $\begin{array}{l}\text { of sexual } \\
\text { abuse do } \\
\text { various ways } \\
\text { to deceive the } \\
\text { victim in } \\
\text { order to } \\
\text { succeed in } \\
\text { carrying out } \\
\text { obscene acts } \\
\text { (P1, K1; and } \\
\mathrm{P} 2, \mathrm{~K} 1, \mathrm{~K} 2) \text {. }\end{array}$ & $\begin{array}{l}\text { crimes } \\
\text { according to } \\
\text { their will } \\
\text { without fear } \\
\text { of applicable } \\
\text { law (P1, K1, } \\
\mathrm{K} 2 \text { and P6, } \\
\mathrm{K} 1, \mathrm{~K} 2) \text {. }\end{array}$ \\
\hline $\begin{array}{l}\text { Make moral } \\
\text { judgement }\end{array}$ & $\begin{array}{l}\text { The violators of } \\
\text { Islamic law are } \\
\text { punished in } \\
\text { accordance with } \\
\text { applicable law } \\
\text { and the media } \\
\text { does not comply } \\
\text { with the } \\
\text { journalistic code } \\
\text { of conduct (P3, } \\
\mathrm{K} 1 \text {; } \mathrm{P} 4 \mathrm{~K} 1 \text {; P5, } \\
\mathrm{K} 1 \text {; } 6, \mathrm{~K} 1 \text {; and } \\
\mathrm{P} 9, \mathrm{~K} 1) \text {. }\end{array}$ & $\begin{array}{l}\text { Men } \\
\text { committed } \\
\text { violations of } \\
\text { the ICC and } \\
\text { Islamic law } \\
\text { will be } \\
\text { processed } \\
\text { legally (P6, } \\
\text { K1 and K2). }\end{array}$ & $\begin{array}{l}\text { The } \\
\text { perpetrator } \\
\text { must be given } \\
\text { sanctions in } \\
\text { accordance } \\
\text { with the } \\
\text { mistakes made } \\
\text { and the } \\
\text { applicable } \\
\text { law, and the } \\
\text { media must } \\
\text { contain more } \\
\text { gender-based } \\
\text { news (P5, K1; } \\
\text { P6, K1; and } \\
\text { P8, K1, K2). }\end{array}$ & $\begin{array}{l}\text { The } \\
\text { perpetrator } \\
\text { must be given } \\
\text { sanctions in } \\
\text { accordance } \\
\text { with the } \\
\text { mistakes } \\
\text { made and the } \\
\text { applicable law } \\
\text { (P4, K1, K2; } \\
\text { and P5, K1, } \\
\mathrm{K} 2 \text { ). }\end{array}$ & $\begin{array}{l}\text { The } \\
\text { perpetrator } \\
\text { must be given } \\
\text { sanctions in } \\
\text { accordance } \\
\text { with the } \\
\text { mistakes } \\
\text { made and the } \\
\text { applicable } \\
\text { law, but not } \\
\text { Shari'a law } \\
\text { (P5, K1 and } \\
\text { K2). }\end{array}$ \\
\hline $\begin{array}{l}\text { Treatment } \\
\text { recommedation }\end{array}$ & $\begin{array}{l}\text { In this news the } \\
\text { recommended } \\
\text { solution is the } \\
\text { settlement by } \\
\text { means of men, } \\
\text { namely by using } \\
\text { the law that has } \\
\text { been set by men } \\
\text { (P3, K1; P7, K1; } \\
\mathrm{P} 8, \mathrm{~K} 1 \text {; and P9, } \\
\mathrm{K} 1 \text { ). }\end{array}$ & $\begin{array}{l}\text { The case } \\
\text { settlement } \\
\text { system } \\
\text { contained in } \\
\text { this news } \\
\text { uses a male } \\
\text { system (P6, } \\
\mathrm{K} 1, \mathrm{~K} 2 \text {, and } \\
\mathrm{K} 3 \text { ). }\end{array}$ & $\begin{array}{l}\text { The solution } \\
\text { used by the } \\
\text { media and the } \\
\text { perpetrators } \\
\text { themselves is } \\
\text { a male method } \\
\text { (P4, K2, K3; } \\
\text { and P9, K1). }\end{array}$ & $\begin{array}{l}\text { The } \\
\text { settlement } \\
\text { used by the } \\
\text { media and the } \\
\text { perpetrators } \\
\text { themselves is } \\
\text { a male } \\
\text { method (P12, } \\
\mathrm{K} 1 \text {; and } \mathrm{P} 13 \text {, } \\
\mathrm{K} 1 \text { ). }\end{array}$ & $\begin{array}{l}\text { The media } \\
\text { contains the } \\
\text { solution used } \\
\text { in men's } \\
\text { manner (P6, } \\
\mathrm{K} 1, \mathrm{~K} 2) \text {. }\end{array}$ \\
\hline
\end{tabular}

\subsection{Analysis of Entman Framing on Violence News}

News of violence against women is still an interesting consumption for the community. Especially in reporting criminal cases such as rape, women are often portrayed as contributing to the cause of the case, not purely as a victim of male crime. Or if there is a case of harassment then it is as if the woman is wrong. In some news narratives, vocabulary use is still sexually oriented, such as "forced to serve lust", "modest body", and so on. The dominance of male media workers and journalists is thought to make the media and the press often trapped in making news or products from men's eyes. Women are considered a commodity that is worth selling. 


\section{Conclusion}

This research was prepared with a background of concern for many women who were victims of acts of violence, both directly and from the mass media. The stereotype of women as 'objects' of men constructed by the mass media, should get a discourse. The discourse on 'women' must be deconstructed. If all this time, women are silent / silent, then from now on they have to speak out loud. Such awareness and courage must continue to be discouraged, not to change the position of women to dominate and construct men, but to balance and balance unequal and unfair relations between the two, due to gender inequality. Islamic Shari'a in force in Aceh today also does not help much to protect Acehnese women. Even violence against women is increasing. This is due to the implementation that is not in accordance with the regulations and the public's perception that the regulation will only curb the community from acting. In fact, if properly reviewed Islamic law supports the people of Aceh to act better and wiser. The news discussed in this study are all types of violent news posted on the Merdeka.com page. However, after the researcher chose the news of violence in Merdeka.com, the news of the violence that was published was only news of sexual violence. The absence of other violence contained in the announcement. In fact, when viewed from the data presented by the researchers, violence that occurs is not only sexual violence, but also other violence. In this study shows that there is a pull of discourse between the local media of Aceh and national media. Where national media should be able to contain news in terms of being different from local media. That can help Acehnese women who experience violence to defend themselves.

\section{Reference}

[1] C. Kramarae, Women and Men Speaking, Framework for Analysis. USA: Newbury House Publishers, inc., 1981.

[2] R. Haryatmoko, Dominasi Penuh Muslihat: Akar Kekerasan dan Diskriminasi. Jakarta: PT. Gramedia Pustaka Utama, 2010.

[3] Sunarto, Televisi, Kekerasan \& Perempuan. Jakarta: Kompas Media Nusantara Wood, 2009.

[4] Balai Pustaka, Kamus Besar Bahasa Indonesia. 2007.

[5] N. Fairclough, Critical Discourse Analysis. New York: Longman Publishing, 2003.

[6] Eriyanto, Analisis Framing (Konstruksi, Ideologi, dan Polotik Media). Yogyakarta: LKiS, 2012.

[7] Abid, M Ainul dkk. 2001. Islam Garda Depan: Mosaik Pemikiran Islam Timur Tengah. Bandung. Mizan.

[8] Abrar, Ana Nadya. 2008. Kebijakan Komunikasi: Konsep, Hakekat dan Praktek. Yogyakarta. Penerbit Gava Media.

[9] Althusser, Louis. 1984. Ideology and Ideological State Aparatuses. London. Verso.

[10] Arismunandar, Satrio. 2012. Kebebasan Pers dan Penerapan Perda Syariat Islam di Aceh.

[11] Bucy, Erik P. 2002. Living in the information age: A new media reader. USA. Wadsworth.

[12] Byerly, Carolyn M. dan Karen Ross. 2006. Women and Media: a Critical Instroduction. USA, UK, Australia. Blackwell Publishing.

[13] Darma, Yoce Aliah. 2013. Analisis Wacana Kritis. Bandung. CV.Yrama Widya.

[14] Eriyanto. 2011. Analisis Wacana Pengantar Analisis Teks Media. Yogyakarta. LKiS.

[15] Griffin, Em. 2009. A First Look At Communication Theory. Boston. Mc. Graw Hill Book Company.

[16] Ismail, Nurjannah. 2007. Syari'at Islam dan Keadilan Gender. First International Conference of Aceh and Indian Ocean Studies. 
[17] Krolokke, Charlotte dan Anne Scott Sorensen. 2006. Gender Communication Theories and Analyses: From Silence to Performance. London. Sage Publications.

[18] Margianto, J. Heru dan Asep Syaefullah. 2012. Media Online: Antara Pembaca, Laba, Dan Etika (Problematika Praktik Jurnalisme Online Di Indonesia). Aliansi Jurnalis Independen (AJI) Indonesia.

[19] Shaw, Alison. 2007. Metode Penelitian Komunikasi: Contoh-Contoh Penelitian Kualitatif Dengan Pendekatan Praktis. Bandung. PT. Remaja Rosdakarya.

[20] Tong, Rosemarie Putnam. 2009. Feminist Thought: Pengantar Paling Komprehensif kepada Arus Utama Pemikiran Feminist. Yogyakarta. Jalasutra.

[21] Usman. 2011. Bias Gender dalam Penafsiran Al-Qur'an: Memahami Pemikiran Nasr Hamid Abu Zayd. Dalam M. Arfan Muammar, Abdul Wahid Hasan dkk. Studi Islam Perspektif Insider/Outsider. Jogjakarta. IRCiSoD.

[22] Walby, Sylvia. 2014. Teorisasi Patriarki. Yogyakarta. Jalasutra.

[23] West, Richard dan Lynn H. Turner. 2010. Teori Komunikasi. Jakarta. Salemba Humanika.

[24] Zoonen, Liesbet Van. 1994. Feminist Media Studies. London. Sage Publication.

[25] Zoonen, Liesbet Van. 2012. Feminist Pespectives on the Media. Dalam Mary Celeste Kearney. The Gender and Media Reader. Oxon. Routledge.

[26] Human Rights Watch. 2010. Menegakkan Moralitas, Pelanggaran dalam Penerapan Syariah di Aceh, Indonesia dalam http://www.hrw.org/fr/node/94464/section/6, akses 5 Mei 2015, jam 21.38 WIB.

[27] Kontras Aceh. 2009. Laporan HAM tahun 2009, diakses melalui http://www.kontrasaceh.org/wp-content/uploads/2011/07/Laporan-HAM-2009.pdf pada 5 Mei 2015, jam 21.38 WIB.

[28] Abar, A. Z dan Tulus Subardjono. 1998. "Perkosaan dalam Wacana Pers National” dalam Jurnal Psikologi. Vol 1:95-105, Kerjasama PPK \& Ford Foundation. Yogyakarta.

[29] Hikmawati, Puteri. 2008. "Relevansi Pelaksanaan Syari'at Islam Di Provinsi Nanggroe Aceh Darussalam Dengan Hukum Pidana Nasional” dalam Kajian, Vol 14:75-90, No. 2, Juni 2008.

]30] Sulistyaningsih, Ekandari. 2012. "Dampak Sosial Psikologis Perkosaan" dalam Buletin Psikologi, Tahun X, No. 1:45-60, Juni 2012.

[31] Setiawan, Yulianto Budi. 2010. Analisis Wacana Kritis Pemberitaan Kekerasan Berbasis Gender di Surat Kabar Harian Suara Merdeka. Tesis Program Magister Ilmu Komunikasi Program Pascasarjana Universitas Diponegoro.

[32] Afif. 2014. Sudah Diperkosa 8 Pemuda, Wanita di Aceh mau Dihukum Cambuk dalam http://www.merdeka.com/peristiwa/ketahuan-berzina-wanita-di-aceh-diarak-diperkosa-8pemuda.html, akses 26 Februari 2015

[33] Anonim. 2012. Masih Ada Kekerasan Pada Perempuan di Media dalam http://aji.or.id/read/berita/163/masih-ada-kekerasan-pada-perempuan-di-media.html, akses 5 Mei 2015.

[34] Anonim. 2014. Media Digital Merupakan Peluang untuk Memperoleh Pengasilan Tambahan dalam http://www.pikiran-rakyat.com/nasional/2014/02/07/269132/media-digital-merupakanpeluang-untuk-memperoleh-penghasilan-tambahan, akses 15 Juni 2015, jam 13.36 wib.

[35] Baihaqi, Aulia. 2005. Wajah Syariat Islam di Bumi Serambi Mekkah dalam http://www.pelita.or.id/baca.php?id=29076, Akses 6 Mei 2015, jam 21.46.

[36] Goenawan, Muhammad Alif. 2015. Pengguna Internet Indonesia Tembus 88,1 Juta dalam http://inet.detik.com/read/2015/03/26/132012/2870293/398/pengguna-internet-indonesia-tembus881-juta, Akses 6 Mei 2015, jam 21.46.

[37] Haryanto, Nur. 2011. Terbukti, Media Online Menyalip Cetak dalam Meraup Kue Iklan dalam http://www.tempo.co/read/news/2011/03/14/072319994/Terbukti-Media-Online-MenyalipCetak-Dalam-Meraup-Kue-Iklan, akses 16 Mei 2015, jam 22.08 wib. 
[38] Team News. 2011. Potensi Iklan Media Online Menjanjikan dalam http://www.balinter.net/news_381_Potensi_Iklan_Media_Online_Menjanjikan.html, akses 04 Mei 2015. 